\title{
THE CHROMOSOMES OF \\ THREE AUSTRALIAN DACETINE ANT SPECIES (HYMENOPTERA: FORMICIDAE)
}

\author{
By R. H. CROzIER* \\ Genetics Department, University of Melbourne, \\ and Department of Entomology and Limnology, \\ Cornell University
}

Although more species of Myrmicinae have been studied cytologically than of any other ant subfamily (Imai, 1966; Hauschteck, I965), there have been no reports on the chromosomes of dacetines. The tribe Dacetini is a very distinct group whose members are mostly specialized feeders on Collembola and whose evolution has been traced in unusual depth for ants (Brown and Wilson, 1959). The species treated here fall into three Australasian genera.

Pharate pupae (prepupae), male pupae, and embryos were pretreated with colcemid. Aceto-carmine-orcein squash preparations were made from Epopostruma and Orectognathus material, and an acetic acid dissociation, air drying technique with aceto-lactic orcein staining (Crozier, 1968a) was also used for Colobostruma and Orectognathus. The criteria used for chromosome classification are those of Levan, Fredga and Sandberg (1964).

The nomenclature followed is that indicated by Brown and Wilson (1959). Identification of the ants was by W. L. Brown, and specimens will be deposited in the Australian National Insect Collection, C. S. I. R. O., Canberra.

\section{Orectognathus clarki (figures I \& 4)}

$$
2 \mathrm{n}=30
$$

Material from Narbethong, Victoria, and Ferntree Gully State Park, Victoria, showed that the karyotype of this species comprises nine pairs of metacentric to submetacentric and six pairs of subacrocentric and acrocentric chromosomes; thus two chromosome groups are discernible (figure 4 ).

$$
\begin{gathered}
\text { Epopostruma sp. (figure 2) } \\
\mathrm{n}=\mathrm{IO}, 2 \mathrm{n}
\end{gathered}
$$

Material from 5 miles W. of Hopetoun, Victoria, has a karyotype

\footnotetext{
*Present address: Department of Entomology and Limnology, Cornell University, Ithaca, New York, 14850, U.S.A.

Manuscript received by the editor February 12, 1968
} 

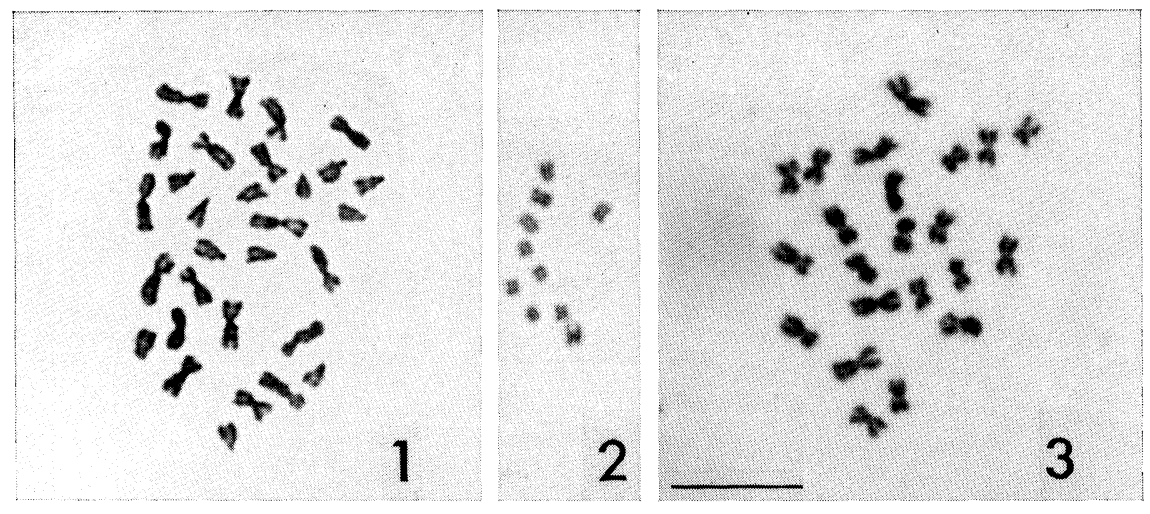

Figures 1-3. Metaphase plates of dacetine species: (1) Orectognathus clarki, Ferntree Gully sample. Diploid cell from air dried preparation of pharate pupal cerebral ganglion (2) Epopostruma sp. Haploid cell from squash preparation of pupal testis. (3) Colobostruma alinodis. Diploid cell from air dried preparation of pharate pupal cerebral ganglion. Line in figure 3 represents 10 microns.

in which all the chromosomes are metacentric, with a more or less continuous gradation in size. A lack of consistent differences precluded grouping the chromosomes.

$$
\begin{gathered}
\text { Colobostruma alinodis (figure } 3 \text { ) } \\
\mathrm{n}=\mathrm{II}, 2 \mathrm{n}=22
\end{gathered}
$$

Material from Ferntree Gully State Park, Victoria, shows a karyotype with eleven metacentric chromosomes. As in the case of the Epopostruma karyotype above, there is a range in size of the chromosomes, but without consistent discontinuities enabling an arrangement of the chromosomes into groups.

\section{DISCUSSION}

In Brown and Wilson's ( 1959) phylogenetic scheme for the Dacetini, Colobostruma and Epopostruma are placed very close together, with Orectognathus some distance away. The cytogenetic results tend to support this placement although, even between the Colobostruma and Epopostruma karyotypes, at least three changes must have occurred (one centric fusion or dissociation, and two pericentric inversions). The difference between these karyotypes and that of Orectognathus clarki is substantial, and speculation about the changes involved would be idle. 
Variation in chromosome number within a genus has now been demonstrated for eight ant genera (Iridomyrmex, Camponotus, Lasius, Formica, Aphaenogaster, Pheidole, Leptothorax and Myrmica - see references), and it would be surprising in view of the divergence between the karyotypes reported here if such variation were not found in further work on the three dacetine genera. In the case of Epopostruma in particular, cytotaxonomy could prove a valuable aid in a genus whose taxonomy is rendered difficult by the tendency of populations to mimic some other locally common ant species (Brown, pers. comm.).

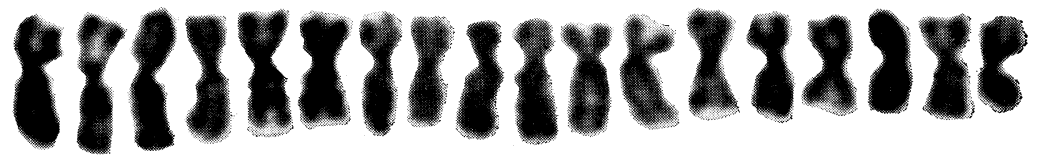

\section{Gohadbaangat}

Figure 4. Diploid karyogram of Orectognathus clarki from cell in figure 1. Line represents 10 microns.

Interpopulation variation in chromosome morphology is indicated in Iridomyrmex of the "detectus" group (Crozier, I968b), and populations of Rhytidoponera metallica vary in chromosome number (Crozier, unpub.), indicating that single-sample karyotype analyses in ants can be misleading, even though karyotypic stability does seem the rule in some ant groups. Unfortunately, few dacetine species are common enough to permit repeated sampling.

Ant cytogenetics is still in a survey period, but this should not prevent the gathering of data on intraspecific karyotypic variation in suitable species.

\section{SUMMARY}

Two samples of Orectognathus clarki showed a haploid chromosome number of 15 , comprising 9 metacentric to submetacentric and 6 subacrocentric to acrocentric chromosomes. A sample of Colobostruma alinodis had I I metacentric chromosomes and one of a species of Epopostruma io metacentric chromosomes, as haploid numbers. 
These observations tend to support present taxonomic placement of these genera, but no simple relationship can be demonstrated between any of the genera.

\section{ACKNOWLEDGEMENTS}

The work on Epopostruma and part of that on Orectognathus is part of a thesis submitted as partial fulfillment of the requirements for the M. Sc. degree, University of Melbourne, and was supported by grants from the C. S. I. R. O. and the University of Melbourne. The work on Colobostruma and part of that on Orectognathus is part of a thesis partially fulfilling the requirements for the Ph.D. degree, Cornell University, and was supported by an Allied Chemical Foundation Grant, and U. S. N. S. F. grant GB5574X, W. L. Brown, Jr., principal investigator. The work was carried out in the Genetics Department, University of Melbourne, and the Entomology Department, Cornell University. I thank Professors M. J. D. White and W. L. Brown for much encouragement and helpful advice.

\section{REFERENCES}

Brown, W. L. AND E. O. Wilson

1959. The evolution of the dacetine ants. Quart. Rev. Biol., 34: 278294.

Crozier, R. H.

1968a. An acetic acid dissociation, air drying technique for insect chromosomes, with aceto-lactic orcein staining. Stain Technol. 43 (in press).

1968b. Interpopulation karyotype differences in Australian Iridomyrmex of the 'detectus' group (Hymenoptera: Formicidae: Dolicho-

HAUSCHTECK, E. derinae). J. Australian Entomol. Soc., 7 (in press).

1965. Halbe haploide Chromosomenzahl im Hoden von Myrmica sulcinodis Nyl. (Formicidae). Experientia, 21: 323-325.

IMAI, H. T.

1966. The chromosome observation techniques of ants and the chromosomes of Formicinae and Myrmicinae. Acta Hymenopterologica, 2: $119-131$.

IMAI, H. T. AND T. H. Yosida

1964. Chromosome observations in Japanese ants. Annual Report Nat. Inst. Genet., Japan, 15: 64-66.

KumbKarni, C. G.

1965. Cytological studies in Hymenoptera Part III. Cytology of parthenogenesis in the formicid ant, Camponotus compressus. Caryologia, 18: 305-311.

Levan, A., K. Fredga and A. A. Sandberg

1964. Nomenclature for centromere position on chromosomes. Hereditas, $52: 201-220$. 

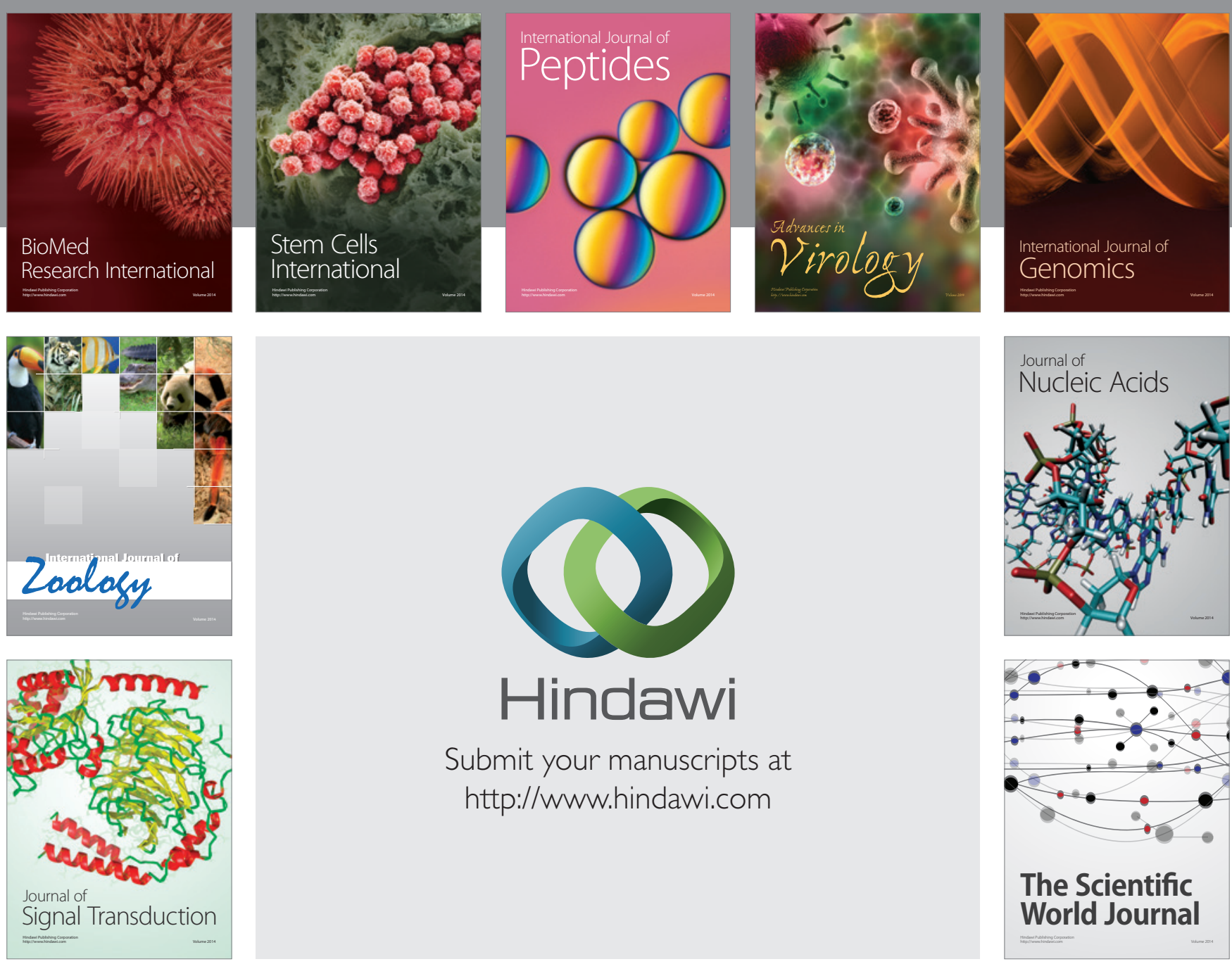

Submit your manuscripts at

http://www.hindawi.com
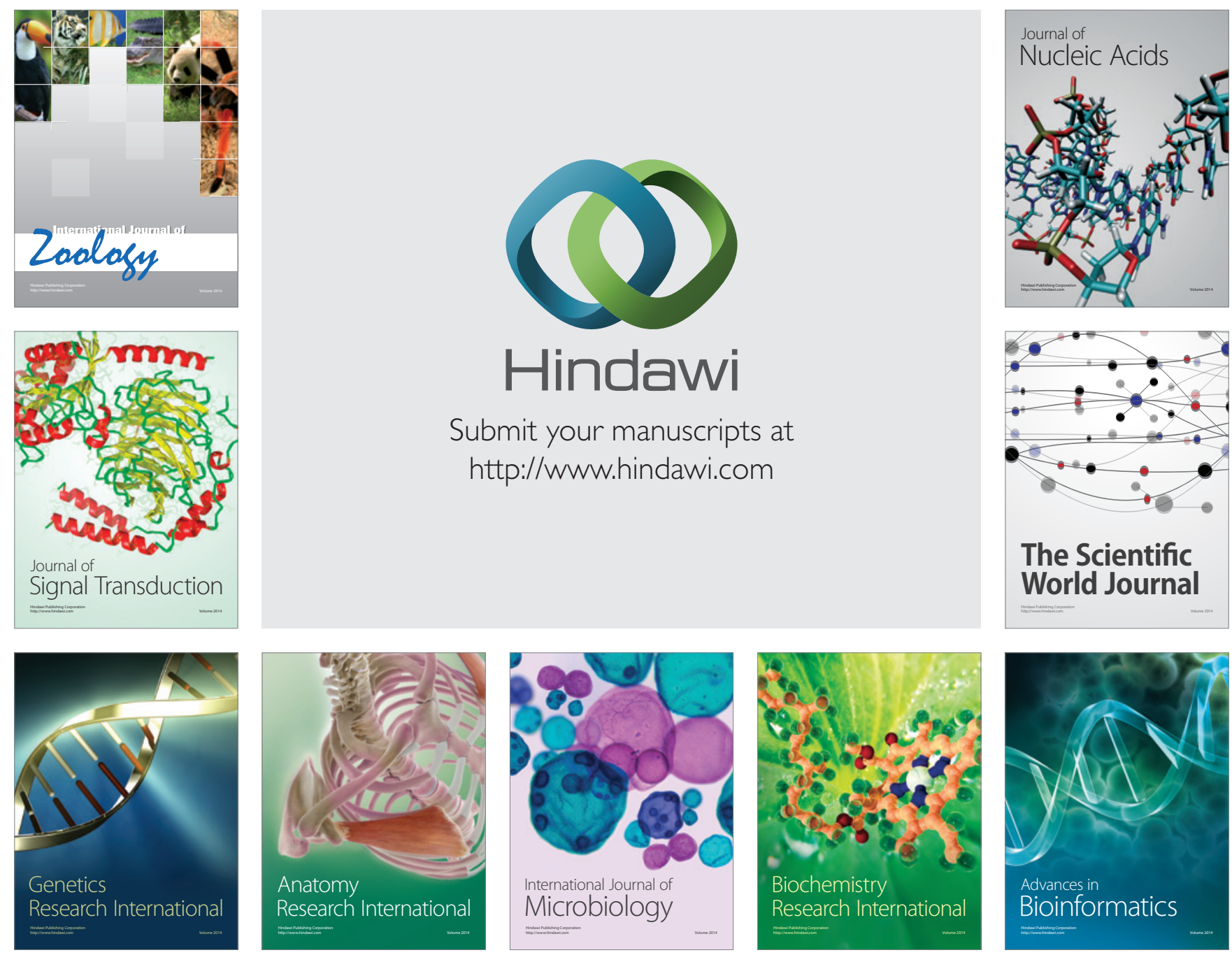

The Scientific World Journal
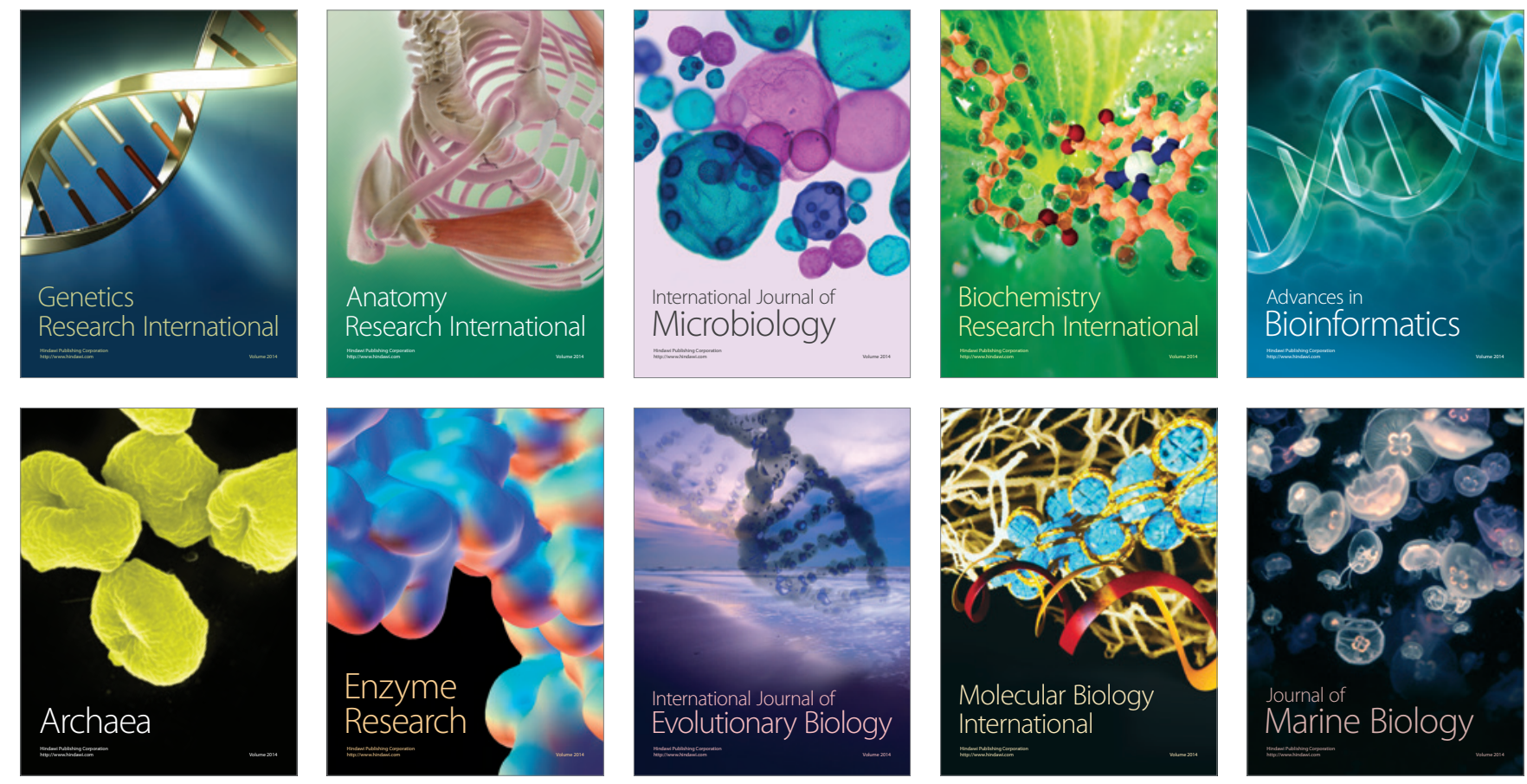